Article

\title{
Intensified Interspecific Competition for Water after Afforestation with Robinia pseudoacacia into a Native Shrubland in the Taihang Mountains, Northern China
}

\author{
Wanrui Zhu ${ }^{1,2} \oplus$, Wenhua $\mathrm{Li}^{1}$, Peili Shi ${ }^{1,2, *}$, Jiansheng Cao ${ }^{3, *}$, Ning Zong ${ }^{1} \oplus$ and Shoubao Geng ${ }^{4}$ \\ 1 Key Laboratory of Ecosystem Network Observation and Modelling, Institute of Geographical Sciences and \\ Natural Resources Research, Chinese Academy Sciences, Beijing 100101, China; \\ zhuwr.16b@igsnrr.ac.cn (W.Z.); liwh@igsnrr.ac.cn (W.L.); zongning@igsnrr.ac.cn (N.Z.) \\ 2 University of Chinese Academy of Sciences, Beijing 100049, China \\ 3 Center for Agricultural Resources Research, Institute of Genetics and Developmental Biology, \\ Chinese Academy of Sciences/Key Laboratory of Agricultural Water Resources, \\ Chinese Academy of Sciences, Shijiazhuang 050022, China \\ 4 Guangzhou Institute of Geography, Guangdong Academy of Sciences, Guangzhou 510070, China; \\ gengshoubao@gdas.ac.cn \\ * Correspondence: shipl@igsnrr.ac.cn (P.S.); caojs@sjziam.ac.cn (J.C.)
}

Citation: Zhu, W.; Li, W.; Shi, P.; Cao, J.; Zong, N.; Geng, S. Intensified Interspecific Competition for Water after Afforestation with Robinia pseudoacacia into a Native Shrubland in the Taihang Mountains, Northern China. Sustainability 2021, 13, 807. https://doi.org/10.3390/su13020807

Received: 18 November 2020 Accepted: 5 January 2021 Published: 15 January 2021

Publisher's Note: MDPI stays neutral with regard to jurisdictional clai$\mathrm{ms}$ in published maps and institutional affiliations.

Copyright: (C) 2021 by the authors. Licensee MDPI, Basel, Switzerland. This article is an open access article distributed under the terms and conditions of the Creative Commons Attribution (CC BY) license (https:// creativecommons.org/licenses/by/ $4.0 /)$.

\begin{abstract}
Understanding how soil water source is used spatiotemporally by tree species and if native species can successfully coexist with introduced species is crucial for selecting species for afforestation. In the rocky mountainous areas of the Taihang Mountains, alien Robinia pseudoacacia L. has been widely afforested into the native shrublands dominated by Ziziphus jujuba Mill var. spinosa and Vitex negundo L. var. heterophylla to improve forest coverage and soil nutrients. However, little is known about the water relation among species, especially seasonal water use sources in different microsites. We selected the soil and plant xylem samples of two opposite microtopographic sites (ridge and valley) monthly in the growth season to analyze isotope composition. The proportions of water sources were quantified by the MixSIAR model and compared pairwise between species, microsites and seasons. We found that deep subsoil water at a depth of 40-50 cm contributed up to $50 \%$ of the total water uptake for R. pseudoacacia and Z. jujuba in the growing season, indicating that they stably used deeper soil water and had intense water competition. However, V. negundo had a more flexible water use strategy, which derived more than $50 \%$ of the total water uptake from the soil layer of $0-10 \mathrm{~cm}$ in the rainy season, but majorly captured soil water at a depth of $30-50 \mathrm{~cm}$ in the dry season. Therefore, high niche overlaps were shown in $V$. negundo with the other two species in the dry season, but niche segregation was seen in the rainy season. The microtopographic sites did not shift the seasonal dynamic of the water source use patterns of the three studied species, but the water use niche overlap was higher in the valley than in the ridge. Taken together, the introduced species R. pseudoacacia intensified water competition with the native semi-arbor species Z. jujuba, but it could commonly coexist with the native shrub species $V$. negundo. Therefore, our study on seasonal water use sources in different microsites provides insight into species interaction and site selection for R. pseudoacacia afforestation in the native shrub community in rocky mountainous areas. It is better to plant $R$. pseudoacacia in the shrubland in the valley so as to avoid intense water competition and control soil erosion.
\end{abstract}

Keywords: Robinia pseudoacacia; afforestation; water competition; stable isotope composition; the Taihang Mountains

\section{Introduction}

Afforestation is one of the main measures for vegetation restoration [1], and several key national ecological restoration programs have been undertaken in China with the long-running aim of fighting against land degradation, and preventing sand and dust 
storms [2,3]. A pattern of mixed trees with shrubs and grasses has been proven to be effective in maintaining forest diversity, stability, and sustainability $[4,5]$. In the rocky mountainous areas of northern China (e.g., the Taihang Mountains) with fragile and infertile soil [6,7], the mixed species afforestation of alien pioneer species, for example Robinia pseudoacacia, with native shrubs has been widely undertaken $[8,9]$. However, how to coordinate the interspecies resource utilization and achieve species coexistence through niche segregation remains a core issue of tree species selection and mixed forest afforestation [10], which still needs further research for maintaining the sustainable benefits of plantations [11].

The Taihang Mountains Afforestation Project is one of the major ecological restoration programs in China. The Taihang Mountains are located in the ecotone between the Loess Plateau and the North China Plain. Natural woodlands were widespread throughout the area's history, but the forests suffered extensive logging before the 1980s. Since the afforestation project was implemented in the 1990s, several tree species e.g., R. pseudoacacia, Platycladus orientalis, Pinus tabulaeformis, and Populus tremula, have been planted with native shrubs to improve forest cover, and have gradually formed secondary forests [12-14]. In recent years, soil nutrient limitation to tree growth raised the concern of selecting appropriate species to improve nutrient supply in the secondary forests. Mounting evidence has shown that introducing nitrogen-fixating tree species mixed with native species is an effective solution to nutrient deficiency in degraded land $[15,16]$. However, there is still little research on the interspecific water use strategies found between alien trees and native shrubs.

Water is one of the main resources that affect the survival of afforested trees in waterlimited areas [17]. Despite multiple sources of available water for plants, such as rainfall, soil water, underground water, river water, and spring water $[5,18-21]$, soil water is well known as the most direct source of available water for plants [22,23]. The uneven distribution of precipitation causes vertical changes in the level of soil water over time, which determines species composition, forest structure, and species coexistence in waterlimited regions $[19,24]$. The spatiotemporal patterns of soil water and the species' adaptive strategies of water uptake have strongly influenced the success of vegetation restoration in fragile regions where water is limited $[25,26]$.

Avoiding excessive competition for limited water sources among co-occurring species, niche segregation has been considered as the fundamental theory of species complementarity and coexistence, which is essential for maintaining a positive relationship between biodiversity and ecosystem functioning [27]. Tree species have unique water uptake strategies to adapt to the spatiotemporal changes of soil water, and thus present seasonal variations in water use pattern and interspecific differences [22,28,29]. Normally, plants preferentially absorb water from stable and continuous sources. For instance, deep-rooted species (e.g., trees and semi-arbors) can take up deeper water sources stably, enabling them to survive and tolerate seasonal water stress, i.e., go without rain for a long time [30-34]; in contrast, most shallow-rooted species (e.g., grasses and semi-shrubs) mainly depend on shallow soil water supplied by precipitation [19,35-40]. The spatial complementarity of water sources causes niche segregation between species which make use of shallow and deep water, often referred to as the "two-layer hypothesis" [29,41]. However, some studies show that species can switch from accessing shallower to deeper sources of water in different seasons $[42,43]$ or during periods of drought $[44,45]$. For example, in water-scarce seasons or sites, some species can cope with water stress by absorbing water from various sources to support niche segregation of resource utilization [46], whereas in water-abundant seasons or sites, co-occurring species have niche overlaps due to using the same, easily accessible water sources, thus showing higher water competition $[47,48]$. Therefore, coexisting species in a complex ecosystem with a variety of species lifeforms show complicated ecological niche characteristics and seasonal variation among species, revealing the interspecific relationship of plant water utilization and the mechanism of species coexistence, which 
is helpful for understanding and predicting the structure and function of ecosystems in water-stress conditions [49,50].

A large number of studies on water use sources have been conducted in arid and semiarid regions, and coastal sand dune systems [40,43,51-55]; however, little is known about the plant water sources of the restored and reconstructed forests in the hilly areas of the Taihang Mountains [21]. The Taihang Mountains Afforestation Project has been primarily carried out for the purpose of conserving water and soil and maintaining regional ecological security $[2,56]$. As it lies in an inland temperate zone affected by monsoons, vegetation restoration often suffers from seasonal drought, which affects the growth and survival of afforested species, and even influences the succession of restored vegetation [7]. Ziziphus jujuba and Vitex negundo are the dominant woody species of native shrub communities, as well as the pioneer species in the water limited areas with strong resistance to water stress in the infertile hilly land $[7,56]$. R. pseudoacacia is an introduced tree species for afforestation dominated by shrubs to improve soil nutrients in the Taihang Mountains [14,57]. These three woody plants are the common species that constitute hilly plant communities, representing a typical afforestation mode of the ecological restoration program. For this reason, we used the stable isotope method to study seasonal water sources and niche segregation of three co-occurring woody species in two typically microtopographic sites, i.e., in the ridge and valley, and explore whether R. pseudoacacia can stably coexist with the other two species after afforestation. Our main objective was to address whether the seasonal variation of water source supply and environmental heterogeneity could affect plant water use strategies and their interspecific relationship. We hypothesized that: (1) interspecific differentiation of plant water source use would present among the co-occurring species with different lifeforms; (2) plant water source use patterns changed seasonally and spatially with water distribution in the soil profiles, which influenced niche differentiation of the studied species; (3) the heterogeneity of soil water conditions in the microtopographic sites affects the proportion of plant water source use.

\section{Materials and Methods}

\subsection{Study Sites and Target Plant Species}

This study was conducted at Taihang Hilly Ecosystem Experimental Station $\left(37^{\circ} 52^{\prime} 44^{\prime \prime} \mathrm{N}, 114^{\circ} 15^{\prime} 50^{\prime \prime}\right.$ E, $354 \mathrm{~m}$ a.s.l.) of the Chinese Academy of Sciences, located in Yuanshi County on the central east slope of the Taihang Mountains, northern China (Figure 1). The station is characterized by a semiarid continental monsoon climate, with annual mean air temperature of $13.2^{\circ} \mathrm{C}$, coldest monthly temperature of $-1.6^{\circ} \mathrm{C}$ in January, and warmest of $26.3^{\circ} \mathrm{C}$ in July [6]. The mean annual precipitation is $570 \mathrm{~mm}$, with over $65 \%$ of the precipitation falling between July and September [58,59]. Mean annual evapotranspiration is $1934 \mathrm{~mm}$, about 3.4 times of the precipitation. The mountainous cinnamon soil, with a lot of pebbles and coarse soil textures, is developed mainly from the weathering of granitic gneiss, partly by limestone and shale. The soil condition is well drained and generally nutrient poor, with a weak capacity for retaining fertilizer and water. Before the 1980s, large areas of mountain forest were logged and reconstructed as secondary forest and plantations through vegetation restoration $[6,59]$.

Considering the topographical difference in soil water conditions, we conducted this research at two microtopographic sites, in the ridge and valley, at a distance of $500 \mathrm{~m}$. At each site, one $\mathrm{HOBO}$ micrometeorological station was installed to automatically record meteorological data at a frequency of every half hour. The data showed that there were no differences in temperature and precipitation except soil moisture between the two sites during the experiment period. The growth status of mixed forests of R. pseudoacacia with $Z$. jujuba and V. negundo was investigated at both microsites (Table 1). R. pseudoacacia grew better in the valley than in the ridge, whereas $Z$. jujuba favored growth in the ridge. No difference was found for the growth of $V$. negundo. 


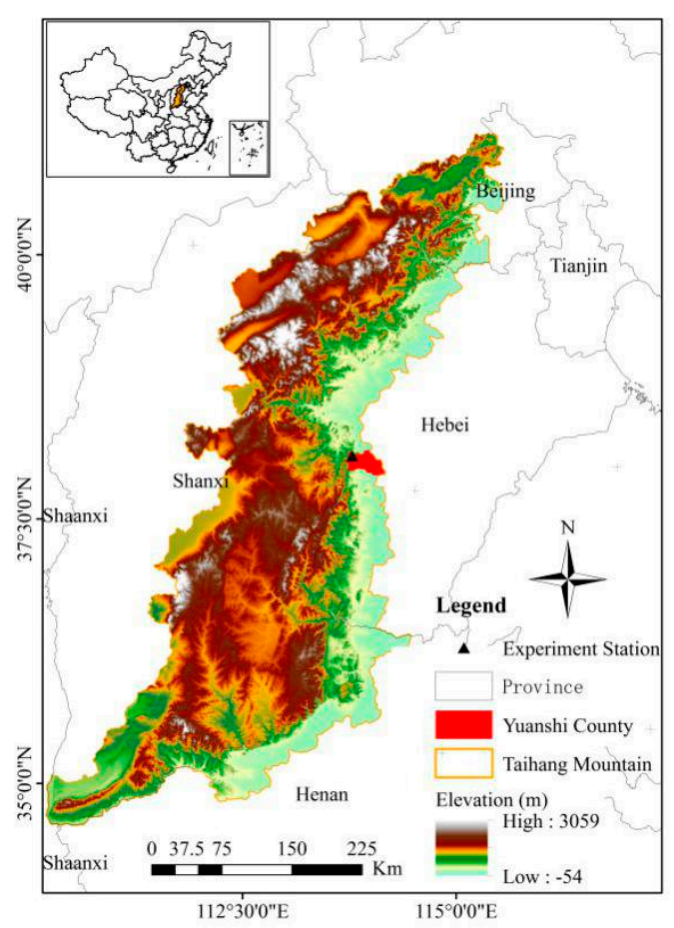

Figure 1. The geographic location of the study in Yuanshi County.

Table 1. The growth status of three co-occurring woody plants in two microtopographic sites.

\begin{tabular}{|c|c|c|c|c|c|}
\hline Microtopographic Site & Site Characteristic & Species & Life Form & $\begin{array}{l}\text { Mean Height } \\
\text { (m) }\end{array}$ & $\begin{array}{c}\text { Average DBH } \\
(\mathrm{cm})\end{array}$ \\
\hline \multirow{3}{*}{ Ridge } & \multirow{3}{*}{$\begin{array}{l}\text { On the top of slope, and } \\
\text { the condition of solar } \\
\text { radiation was the } \\
\text { strongest }\end{array}$} & R. pseudoacacia & Arbor & $3.54 \pm 0.20 \mathrm{~b}$ & $5.04 \pm 0.22 \mathrm{~b}$ \\
\hline & & Z.jujuba & $\begin{array}{c}\text { Semi-arbor/ } \\
\text { shrub }\end{array}$ & $4.00 \pm 0.21 \mathrm{a}$ & $5.21 \pm 0.44 \mathrm{a}$ \\
\hline & & V. negundo & Shrub & $2.90 \pm 0.13 \mathrm{a}$ & $2.82 \pm 0.15 \mathrm{a}$ \\
\hline \multirow{3}{*}{ Valley } & \multirow{3}{*}{$\begin{array}{l}\text { On the bottom of slope, } \\
\text { which connect with the } \\
\text { flat terrain }\end{array}$} & R.pseudoacacia & Arbor & $5.35 \pm 0.25 a$ & $8.04 \pm 0.54 \mathrm{a}$ \\
\hline & & Z.jujuba & $\begin{array}{c}\text { Semi-arbor / } \\
\text { shrub }\end{array}$ & $3.83 \pm 0.28 b$ & $4.08 \pm 0.42 \mathrm{~b}$ \\
\hline & & V. negundo & Shrub & $2.79 \pm 0.09 \mathrm{a}$ & $2.35 \pm 0.10 \mathrm{a}$ \\
\hline
\end{tabular}

The lowercase letters $(a, b)$ represented significant differences of tree height and diameter at breast height (DBH) for the same species between the ridge and the valley sites $(p<0.05)$.

\subsection{Sample Collection and Stable Isotope Analyses}

Five plots $(10 \mathrm{~m} \times 10 \mathrm{~m})$, separated by at least $100 \mathrm{~m}$, were chosen for sample collection at each of the two microtopographic sites. In each plot, a sampling point with three target species growing together and similar coverage to the corresponding plot was used for sampling. The samples were collected on two consecutive sunny days of each month, once a month, from May to September 2017. For each sampling time, samples were collected in 10 plots (five plots $\times$ two microtopographic sites). Therefore, five replicate sampling points were used for each sampling site and month. A total of 8-10 segments of non-photosynthetic and lignified twigs from each target species in each sampling point were clipped and mixed as one sample from the sunward canopy of each species. To maximally reduce the risk of stem water evaporation, the peeled xylem parts of the stem segments were immediately put into screw-cap vials, and then sealed with parafilm [60]. Concurrently, soil samples were collected at the same locations under the canopy of plant sampling. In each point, soil samples were collected with soil auger in 5 layers with an interval of $10 \mathrm{~cm}$ and then divided into 2 parts. One part was sealed in screw-cap vials for water extraction and isotopic analyses; the other part was stored in aluminum 
boxes to measure gravimetric soil water content. All plant stems and soil samples were immediately placed into a portable cooler and then stored in a refrigerator at $-20{ }^{\circ} \mathrm{C}$ until water extraction and isotopic analysis.

Water from plant xylem and soil samples was extracted by a cryogenic vacuum distillation system (LI-2100, Lica United, Beijing, China) and then filtered using a $0.2-\mu \mathrm{m}$ filter before stable isotopic analysis. The stable isotope composition of hydrogen $\left(\delta^{2} \mathrm{H}\right)$ and oxygen $\left(\delta^{18} \mathrm{O}\right)$ in water were determined by a laser absorption water vapor isotope analyzer (Picarro-i2120, Santa Clara, CA, USA) at the Key Laboratory of Agricultural Water Resources, Chinese Academy of Science [61]. The isotope ratio of $\delta^{2} \mathrm{H}$ or $\delta^{18} \mathrm{O}$ expressed in standard $\delta$-notation as per mil (\%o) was calculated as

$$
\delta^{2} \mathrm{H} /{ }^{18} \mathrm{O}(\%)=\left(R_{\text {sample }} / R_{\text {standard }}-1\right) \times 1000
$$

where $R_{\text {sample }}$ and $R_{\text {standard }}$ are the isotope ratio $\left({ }^{2} \mathrm{H} /{ }^{1} \mathrm{H},{ }^{18} \mathrm{O} /{ }^{16} \mathrm{O}\right)$ of the sample and standard (Vienna Standard Mean Ocean Water, VSMOW), respectively. The analytical precision is $\pm 0.5 \%$ o for $\delta^{2} \mathrm{H}$ and $\pm 0.2 \%$ o for $\delta^{18} \mathrm{O}$.

\subsection{Quantifying the Proportion of Water Use Sources}

A Bayesian stable isotope mixing model (MixSIAR) for $\mathrm{R}$ was used to calculate the relative contribution of water use sources to plant growth [62-64]. The raw xylem isotope values $\left(\delta^{2} \mathrm{H}\right.$ and $\left.\delta^{18} \mathrm{O}\right)$ from three co-occurring species in two microtopographic sites were used as mixture data. The means and standard errors of isotope ratios $\left(\delta^{2} \mathrm{H}\right.$ and $\left.\delta^{18} \mathrm{O}\right)$ from five soil layers were used as source data, which had no concentration dependence but varied by species and sites. The discrimination data were set as zero because no fractionation occurred in $\delta^{2} \mathrm{H}$ and $\delta^{18} \mathrm{O}$ during plant water uptake [65]. Fixed effects (species and microtopographic sites), where species were nested within microtopographic sites, were conducted in all analyses. Markov Chain Monte Carlo (MCMC) parameters were specified as "very long" (number of chains $=3$, chain length $=1,000,000$, burn-in $=500,000$, thin =500), aiming to converge on the posterior distributions for all variables in the model [66]. Before accepting any of the MixSIAR results, we ensured that the model had converged. Gelman-Rubin and Geweke diagnostic tests were conducted to ascertain whether the model was close to convergence [67]. We chose the "Residual * Process" option of error structure and set it to "uninformative prior" in the model [63]. Finally, we ran the MixSIAR model and obtained the process output. The median values were presented as the proportional contribution of water sources to plant species.

\subsection{Species Niche Overlap of Water Use}

Pairwise niche overlap of co-occurring species was calculated using the index of proportional similarity (PS) based on Trogisch et al. [68] and Hoekstra et al. [69]:

$$
P S=1-0.5 \sum_{i=1}^{n}\left|p_{1 i}-p_{2 i}\right|
$$

where $p_{1 i}$ and $p_{2 i}$ represented the proportional contribution (in $\%$ ) to water uptake of the vertical soil depth intervals within species. The value of PS is minimum (0) when there is no overlap of water use source between two species, and is maximum (1) when there is complete overlap.

\subsection{Statistical Analysis}

Statistical analyses were performed using SPSS 17.0 (SPSS Inc., Chicago, IL, USA). One-way ANOVA was used to calculate the means and standard errors and test significant differences of the data among species and soil layers in different seasonal periods and at different sites. Multi-factor ANOVA was conducted to test the interaction effects of site, season, and soil depth on soil water content (SWC) and soil water isotopic values, and also quantify the effects of site, season, and species on plant xylem water isotopic values. We 
used the least-significant difference (LSD) test (at level of $\alpha=0.05$ ) nested in multi-factor ANOVA to determine whether there was a significant difference in the periods of season, site, soil depth, or species. All pictures were graphed with OriginPro 2016 (Origin Lab Corp., Northampton, MA, USA).

\section{Results}

\subsection{Variation in Soil Water Content}

The seasonal and vertical variations of SWC showed similar trends in two microtopographic sites during the studied season, while the mean values of SWC in different soil depths were significantly higher in the valley than in the ridge (Figure 2, Table 2). The main effects of season and soil depth presented significant differences in SWC (Table 2). During the growing season, there was a summer peak of SWC in August and a spring lowest in June. In the dry season, the SWC decreased slowly with soil depth and showed a significant layer difference between $0-10 \mathrm{~cm}$ and $40-50 \mathrm{~cm}$. In the rainy season, the SWC decreased more steeply with soil depth, with significantly lower SWC at the soil layer below $30 \mathrm{~cm}$ than that at $10 \mathrm{~cm}$ (Figure 2). The SWC of each soil layer continuously decreased after August but showed no significant difference below the depth of $30 \mathrm{~cm}$ in May and September.

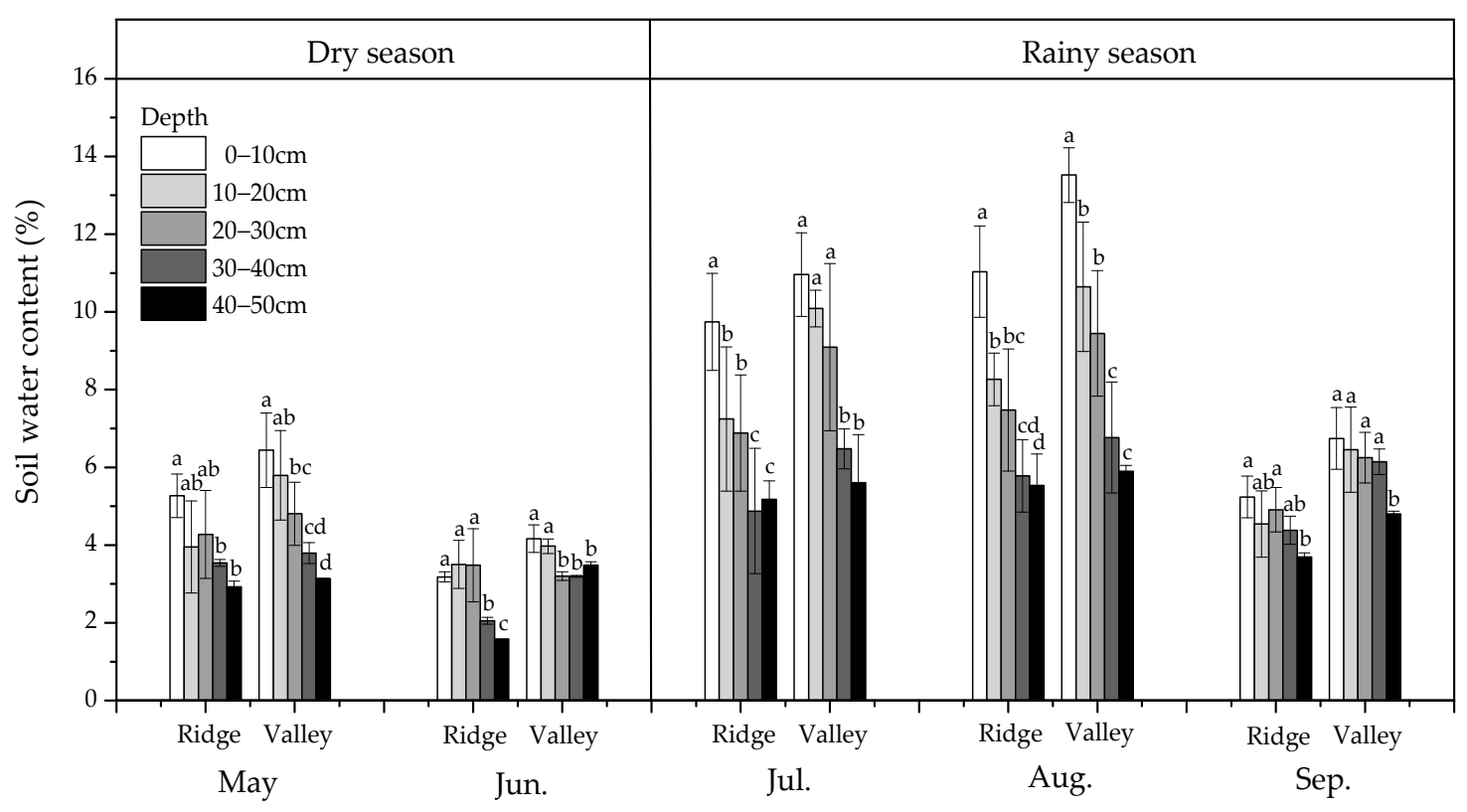

Figure 2. Vertical distribution and seasonal variation of soil water content in the ridge and valley. Different lowercase letters above the histograms refer to the significant difference of the soil water content among five soil layers with $10 \mathrm{~cm}$ interval in the same site and month.

\subsection{Isotopic Values of All Water Samples}

\subsubsection{Variation in Soil Water Isotopic Values}

The isotopic values of $\delta^{18} \mathrm{O}$ and $\delta^{2} \mathrm{H}$ of soil water both varied significantly at different soil layers, in different periods of season, between microtopographical sites, and with interaction among them (Table 2). Spatially, the $\delta^{18} \mathrm{O}$ and $\delta^{2} \mathrm{H}$ values decreased with increasing soil depths because of reduced evaporation and isotope fractionation. However, there was an exception in the dry season (May and June) with more negative isotope values of shallower soil layers above $20 \mathrm{~cm}$ and fewer changes of subsoil layers below $20 \mathrm{~cm}$ in the valley (Figure 3). Isotopic values of subsoil layers $(30-50 \mathrm{~cm})$ between the two sites were significantly different in May, June, and July (Figure 3). Seasonally, the isotopic values of $\delta^{18} \mathrm{O}$ and $\delta^{2} \mathrm{H}$ fluctuated more substantially over time in the shallower soil layer $(0-10 \mathrm{~cm})$ than in the other subsoil layers due to the interaction of precipitation and evaporation. The 
isotopic values of soil water were less negative in the dry season (May to June) than in the rainy season (July to September), showing a more enriched heavy isotope due to strong evaporation and less depletion due to limited precipitation in the dry season (Figure 3).

Table 2. Multi-factor ANOVA for analyzing the main and interaction effects of microtopographic site, seasonal periods, and soil depth on soil water content and isotopic values $\left(\delta^{18} \mathrm{O}\right.$ and $\left.\delta^{2} \mathrm{H}\right)$.

\begin{tabular}{|c|c|c|c|c|c|c|c|}
\hline \multirow{2}{*}{ Fixed Effect } & \multirow{2}{*}{ df } & \multicolumn{2}{|c|}{ Soil Water Content (\%) } & \multicolumn{2}{|c|}{$\delta^{18} \mathrm{O}_{\text {soil }}(\%)$} & \multicolumn{2}{|c|}{$\delta^{2} \mathrm{H}_{\text {soil }}(\%)$} \\
\hline & & $F$ & $p$ & $F$ & $p$ & $F$ & $p$ \\
\hline Microtopographic site & 1 & 82.978 & $<0.001$ & 10.428 & 0.002 & 7.487 & 0.007 \\
\hline Periods of season & 4 & 191.476 & $<0.001$ & 77.205 & $<0.001$ & 33.773 & $<0.001$ \\
\hline Soil depth & 4 & 75.515 & $<0.001$ & 13.471 & $<0.001$ & 7.703 & $<0.001$ \\
\hline $\begin{array}{l}\text { Microtopographic site } \times \\
\text { periods of season }\end{array}$ & 4 & 1.860 & 0.119 & 46.974 & $<0.001$ & 14.326 & $<0.001$ \\
\hline $\begin{array}{l}\text { Microtopographic site } \times \\
\text { soil depth }\end{array}$ & 4 & 1.659 & 0.161 & 3.122 & 0.019 & 1.571 & 0.189 \\
\hline Soil depth $\times$ periods of season & 16 & 7.431 & $<0.001$ & 4.007 & $<0.001$ & 1.057 & 0.408 \\
\hline $\begin{array}{l}\text { Soil depth } \times \text { periods of season } \\
\times \text { microtopographic site }\end{array}$ & 16 & 1.052 & 0.404 & 5.147 & $<0.001$ & 3.222 & $<0.001$ \\
\hline
\end{tabular}
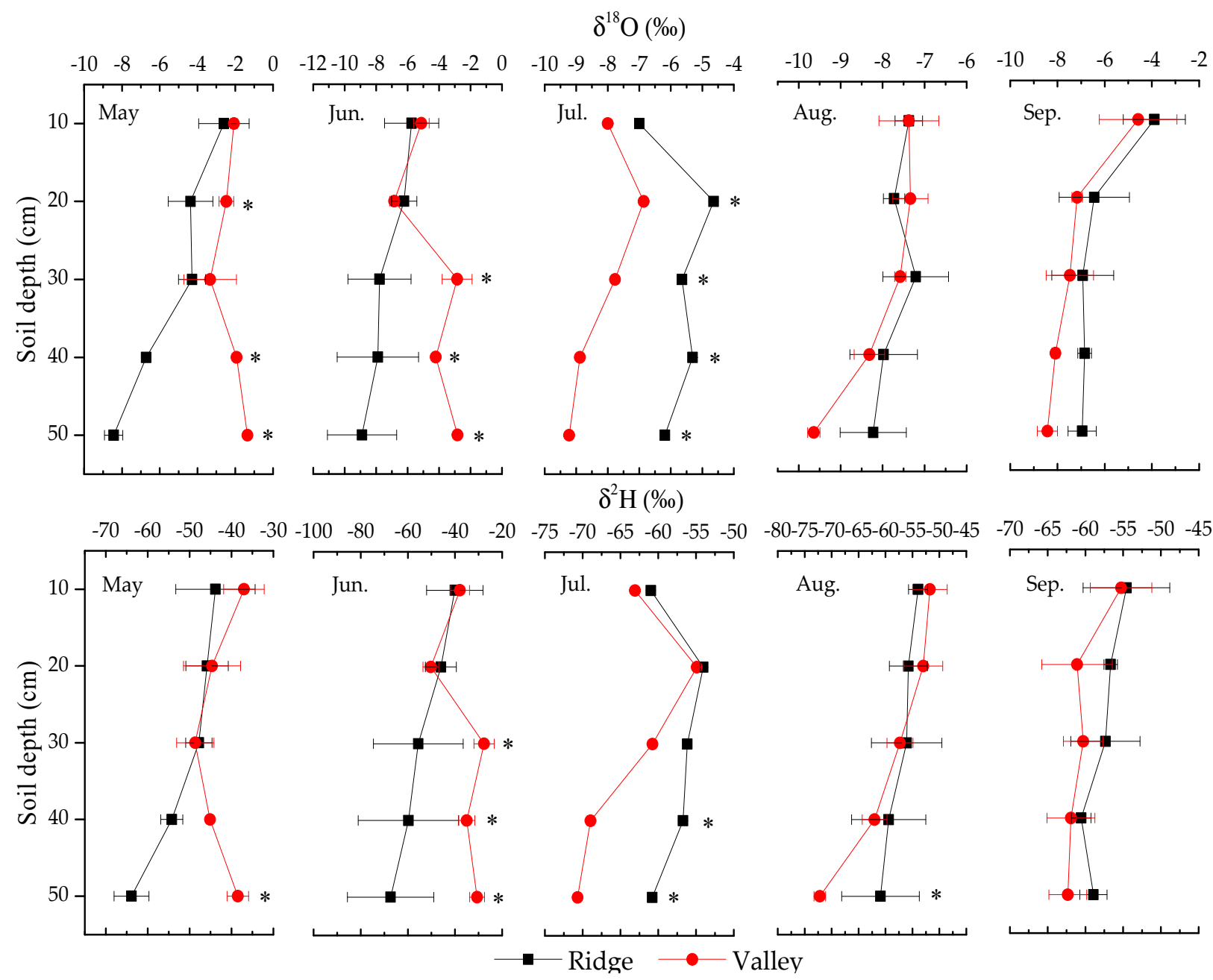

Figure 3. Seasonal and vertical variations of the soil water $\delta^{18} \mathrm{O}$ and $\delta^{2} \mathrm{H}$ in the ridge (black square) and valley (red circle). The asterisk $(*)$ indicates significant difference of soil water isotopic values between microtopographic sites in same soil layer and period of season $(\alpha=0.05)$. 


\subsubsection{Variation in Plant Xylem Water Isotopic Values}

The isotopic values of plant xylem water showed differences among species and periods of season, but no differences between microtopographic sites (Table 3). The average $\delta^{18} \mathrm{O}$ and $\delta^{2} \mathrm{H}$ values of R. pseudoacacia and $Z$. jujuba were more negative than that of $V$. negundo, but there was no difference between R. pseudoacacia and Z. jujuba. Differences in the isotopic values of species were not noticeable in the dry season, but were clearly intensified during the rainy season (Figure 4). The seasonal plant xylem $\delta^{2} \mathrm{H}$ and $\delta^{18} \mathrm{O}$ values of $V$. negundo increased from the dry season to the rainy season. However, those of $R$. pseudoacacia varied significantly only in the dry season, but there was no difference in the rainy season, with a minimum in May. In comparison, those of Z. jujuba changed little between seasons (Figure 4).

Table 3. Multi-factor ANOVA for calculating the main effects and interaction of species, microtopographic site, periods of season on plant stem water isotopic values.

\begin{tabular}{|c|c|c|c|c|c|}
\hline \multirow{2}{*}{ Fixed Effect } & \multirow{2}{*}{ df } & \multicolumn{2}{|c|}{$\delta^{18} \mathrm{O}_{\text {xylem }}(\%)$} & \multicolumn{2}{|c|}{$\delta^{2} \mathbf{H}_{\text {xylem }}(\%)$} \\
\hline & & $F$ & $p$ & $F$ & $p$ \\
\hline Microtopographic site & 1 & 3.348 & 0.073 & 5.285 & 0.025 \\
\hline Species & 2 & 29.098 & $<0.001$ & 32.173 & $<0.001$ \\
\hline Periods of season & 4 & 14.104 & $<0.001$ & 23.995 & $<0.001$ \\
\hline Species $\times$ microtopographic site & 2 & 4.270 & 0.019 & 4.362 & 0.018 \\
\hline Microtopographic site $\times$ periods of season & 4 & 3.788 & 0.009 & 6.067 & $<0.001$ \\
\hline Species $\times$ periods of season & 8 & 1.813 & 0.095 & 2.713 & 0.014 \\
\hline Species $\times$ periods of season $\times$ microtopographic site & 8 & 1.073 & 0.396 & 1.005 & 0.443 \\
\hline
\end{tabular}

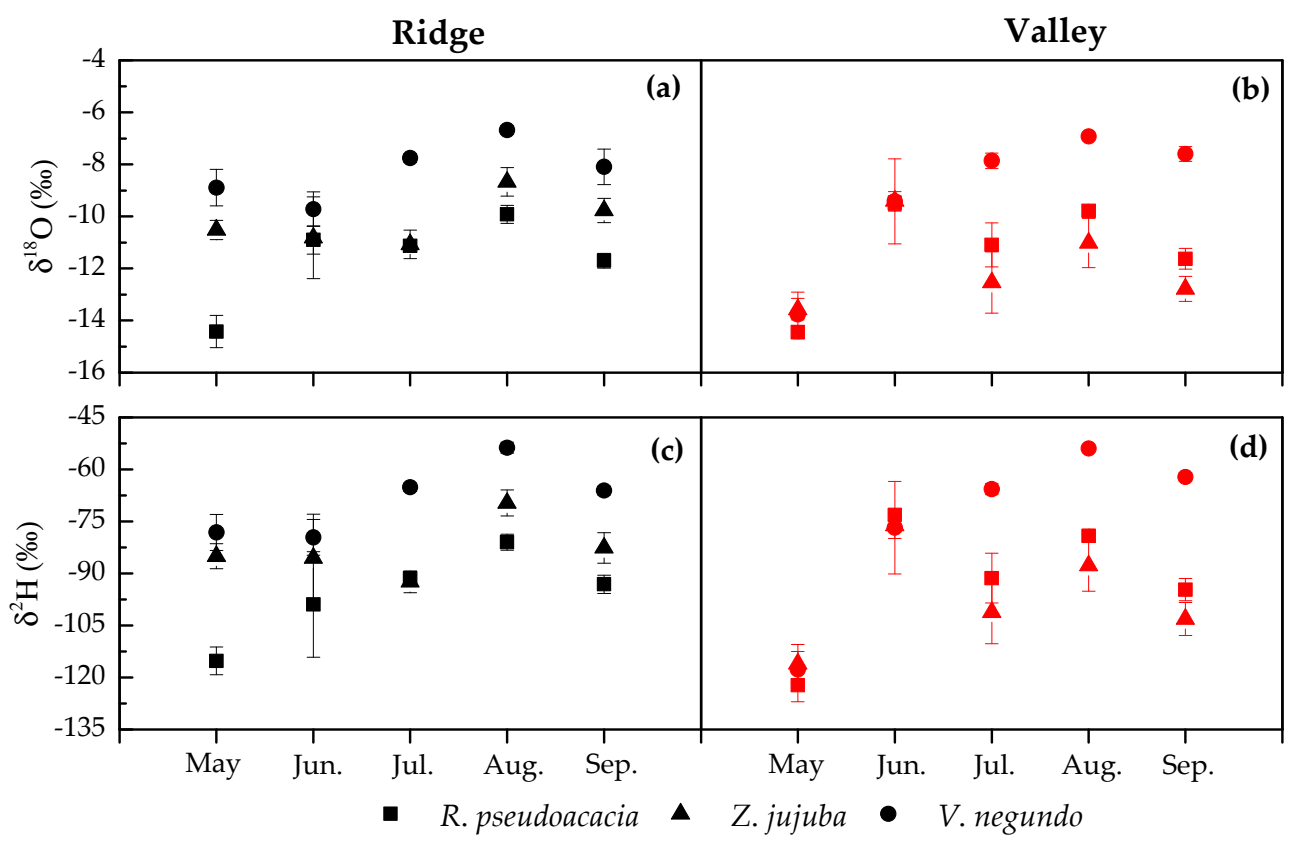

Figure 4. Seasonal variations of xylem isotopic values of R. pseudoacacia (squares), Z. jujuba (triangles) and $V$. negundo (circles) in the ridge $(\mathbf{a}, \mathbf{c})$ and valley $(\mathbf{b}, \mathbf{d})$. Average values with standard errors of species are shown.

\subsection{Proportion of Plant Water Source Utilization}

On the whole, there were more major sources of water uptake in the humid valley than in the relatively drier ridge (Figure 5).

During the dry season, no marked species differences occurred in the water source of the same soil layer (Figure 5). However, water uptake proportion of different soil depths changed with seasons and sites. In May, all studied species used a higher proportion, up 
to $50 \%$ of water from subsoil at a depth of $40-50 \mathrm{~cm}$ in the ridge (Figure $5 \mathrm{a}-\mathrm{c}$ ), while they took an equal proportion, approximately $40 \%$ of water from $20-30,40-50 \mathrm{~cm}$ soil, in the valley (Figure $5 \mathrm{~d}-\mathrm{f}$ ). In June, these species utilized water evenly at each layer below a depth of $10 \mathrm{~cm}$ in the ridge (Figure $5 \mathrm{a}-\mathrm{c}$ ), but were convergent in taking up water from the $10-20 \mathrm{~cm}$ soil layer in the valley (Figure $5 \mathrm{~d}-\mathrm{f}$ ).

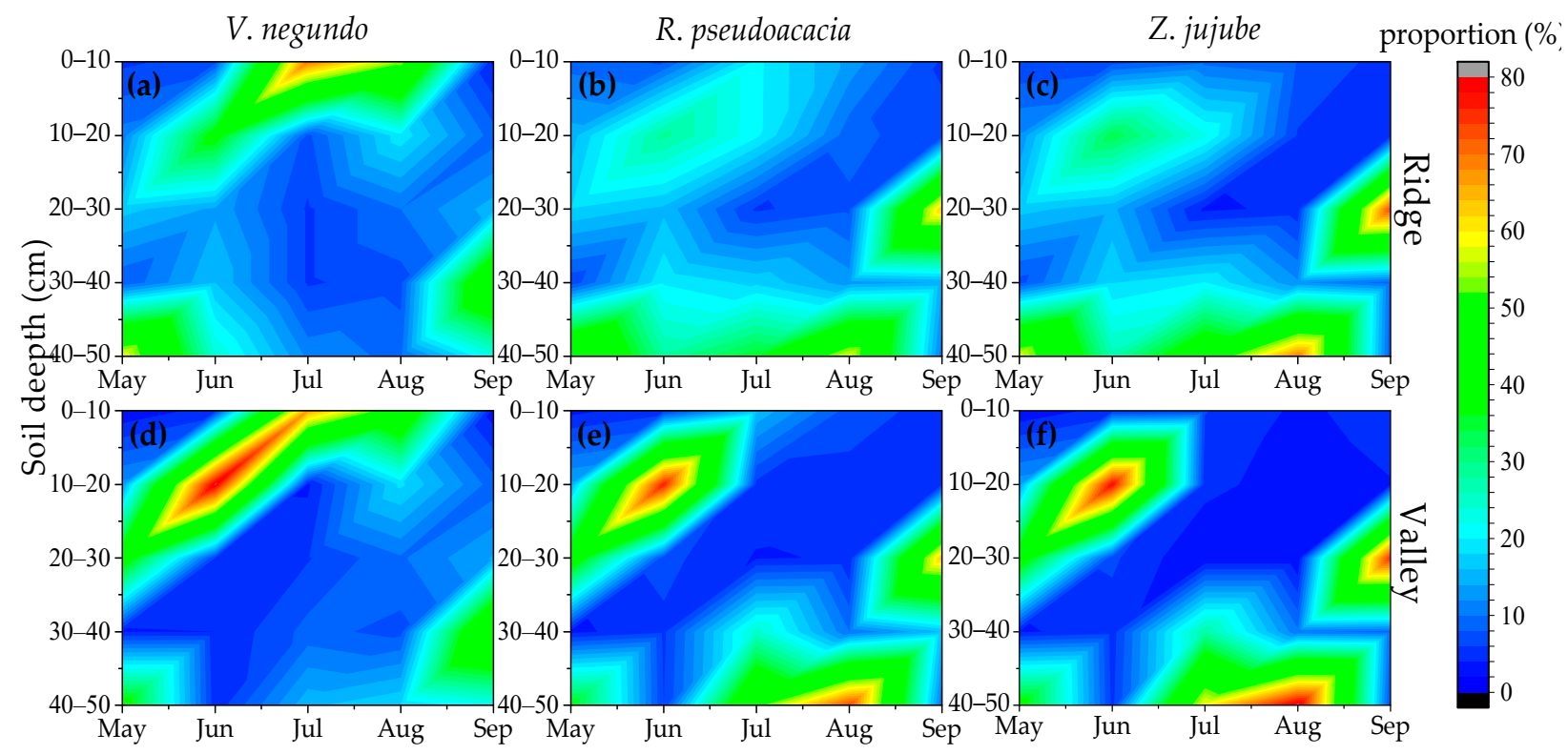

Figure 5. Seasonal variations in the proportion of water uptake from different soil depths for V. negundo, R. pseudoacacia, and Z. jujuba in the ridge $(\mathbf{a}-\mathbf{c})$ and valley $(\mathbf{d}-\mathbf{f})$. The asymptotic color represents the contribution proportion of water uptake from different soil depths, with red end and blue end indicating the highest and lowest contribution proportion of water source, respectively.

During the rainy season, $V$. negundo mainly derived up to $60 \%$ and $40 \%$ of the water from surface soil above $10 \mathrm{~cm}$ in July and August, respectively, and showed no significant difference between sites (Figure 5a,d). However, similar to the dry season, R. pseudoacacia and Z. jujuba both continued to utilize water stably from the soil layer of $40-50 \mathrm{~cm}$ in July and August (Figure 5b,c,e,f). In September, with the decrease in soil water, $V$. negundo started to absorb deeper soil water at a depth of $30-40 \mathrm{~cm}$ whereas R. pseudoacacia and Z. jujuba explored shallower soil water of 20-30 cm (Figure 5).

\subsection{Interspecific Niche Overlap}

The indices of water use niche overlap in specific pairwise species among the studied species were higher in the dry season than in the rainy season, and better water availability strengthened niche overlap between species in the valley in contrast to the water-limited ridge site. For example, more species niche overlap of water source use was found between R. pseudoacacia and Z. jujuba, with PS values over $90 \%$ in the dry season and up to $80 \%$ in the rainy season, and higher overlap in the valley than in the ridge. However, the $P S$ values of $V$. negundo with R. pseudoacacia and $Z$. jujuba varied in different periods of the growing season. $V$. negundo showed high niche overlap with R. pseudoacacia and Z. jujuba in the dry season, but shifted to niche segregation with R. pseudoacacia and Z. jujuba in the rainy season (Table 4 ). 
Table 4. Niche overlap between species in the dry season ( $i=10,5$ soil layers $\times 2$ months), in the rainy season $(i=15,5$ soil layers $\times 3$ months $)$ and in the whole season $(i=25,5$ soil layers $\times 5$ months $)$.

\begin{tabular}{|c|c|c|c|c|c|c|c|}
\hline \multirow{2}{*}{$\begin{array}{l}\text { Periods of } \\
\text { Season }\end{array}$} & \multirow{2}{*}{ Species } & \multicolumn{3}{|c|}{ Ridge } & \multicolumn{3}{|c|}{ Valley } \\
\hline & & R. pseudoacacia & Z.jujuba & V. negundo & R. pseudoacacia & Z.jujuba & V. negundo \\
\hline \multirow{3}{*}{$\begin{array}{c}\text { Dry } \\
\text { season }\end{array}$} & R. pseudoacacia & $100 \%$ & & & $100 \%$ & & \\
\hline & Z. jujuba & $94.20 \%$ & $100 \%$ & & $97.73 \%$ & $100 \%$ & \\
\hline & V.negundo & $90.43 \%$ & $96.13 \%$ & $100 \%$ & $96.38 \%$ & $98.55 \%$ & $100 \%$ \\
\hline \multirow{3}{*}{$\begin{array}{l}\text { Rainy } \\
\text { season }\end{array}$} & R.pseudoacacia & $100 \%$ & & & $100 \%$ & & \\
\hline & Z. jujuba & $82.20 \%$ & $100 \%$ & & $83.98 \%$ & $100 \%$ & \\
\hline & V. negundo & $23.58 \%$ & $6.43 \%$ & $100 \%$ & $18.95 \%$ & $3.38 \%$ & $100 \%$ \\
\hline \multirow{3}{*}{$\begin{array}{l}\text { Whole } \\
\text { season }\end{array}$} & R. pseudoacacia & $100 \%$ & & & $100 \%$ & & \\
\hline & Z. jujuba & $76.40 \%$ & $100 \%$ & & $81.70 \%$ & $100 \%$ & \\
\hline & V. negundo & $14.00 \%$ & $2.55 \%$ & $100 \%$ & $15.33 \%$ & $1.93 \%$ & $100 \%$ \\
\hline
\end{tabular}

\section{Discussion}

\subsection{Soil Water Content and Its Isotopic Composition}

The isotopic composition of soil water is mainly affected by evaporation and osmotic processes, as well as the mixing of new and old rainwater [70,71]. In our study, the $\delta^{2} \mathrm{H}$ and $\delta^{18} \mathrm{O}$ values of soil water presented more negatively in the rainy season than in the dry season, indicating isotopic depletion in the rainy season. Our results agree with Deng et al. [72] who found that more isotopic composition enrichment occurred in the dry season than in the wet season. In soil strata, the soil water isotopic values of $\delta^{2} \mathrm{H}$ and $\delta^{18} \mathrm{O}$ were higher at surface $(0-10 \mathrm{~cm})$ than other soil layers because water evaporation strongly occurs in the surface soil $[30,70,73]$. Additionally, due to water transfer and accumulation in lowlying areas through surface runoff and infiltration after rainfall, and being less subject to wind, which greatly reduces the evaporation of soil water [56], SWC was significantly higher in the valley than in the ridge, especially in soil layers of $0-30 \mathrm{~cm}$. However, even though the SWC is higher in the valley, the isotopic values of subsoil layers $(30-50 \mathrm{~cm})$ were normally enriched compared to the ridge during the dry season (Figure 3). Thus, we speculate that this result may be due to occasionally low-intensity rainfall, which could not easily infiltrate soil layer below $30 \mathrm{~cm}$, or the greater tree height of R.pseudoacacia creating a different canopy density which influenced the isotopic composition [30].

\subsection{Seasonal Variation of Water Source Use in Different Species}

The seasonal variation of the isotopic composition of water in xylem can reflect the difference of water sources and water use strategies among species [74]. V. negundo used a water source majorly from a shallow $(0-10 \mathrm{~cm})$ soil layer in July and August, yet shifted to use soil water below $20 \mathrm{~cm}$ in the dry season. The result is consistent with the study of Zhao et al. [75], who found that the main water use source of the shrub V. negundo was from the soil layers above $30 \mathrm{~cm}$. In fact, the plasticity of soil water use in different periods of the growing season is closely associated with plant root traits and root distribution in the soil profile. Many plants in arid and semi-arid ecosystems possess a functionally dimorphic root system, which has a zone of lateral roots to predominantly acquire water from surface soil during wet seasons, while deriving water through the tap root from deep soil layers when surface water is unavailable in the dry seasons $[65,76]$. The dimorphic root species normally switch to absorbing water mainly from shallow to deep soil layers in the dry season $[5,65]$. Accordingly, plants with dimorphic root systems are more competitive than those solely depending on surface soil water in water-limited environments [36]. As studies have reported that $V$. negundo has a dimorphic root, with a set of lateral roots radiating from the main root crown and one or more deeply penetrating tap (sinker) roots [66], we also observed in our sites that the extensive network of lateral roots was predominantly concentrated in the top $30 \mathrm{~cm}$ soil layer with the highest root surface area, allowing $V$. negundo to monopolize the shallow moisture. The flexible water use strategy explains the 
widespread distribution of the shrub V. negundo in semiarid northern China. R. pseudoacacia and Z.jujuba both have a coarse, deeper tap root to fix plants and a series of lateral fine roots growing from a deep tap root. The deeper root systems of these two tree species enable their capacity to use water in the subsoil at 40-50 cm regardless of dry or rainy season. Besides, R. pseudoacacia and Z. jujuba can also take up water from soil layers below 10-20 cm in the dry season (particularly evident in June, Figure 5e,f) because, on the one hand, water was redistributed by plant roots lifting deep soil water to the shallower layer and using it [77-80]; on the other hand, water acquisition of fine roots in a shallow layer increased as a result of less water or low frequency of a small rainfall event in the dry season penetrating the deep soil. For R. pseudoacacia and Z. jujuba, there were no significant differences of isotopic values and seasonal variation, which implied that these two plants (arbor and semi-arbor) can stably use water from subsoil till to a depth of $40-50 \mathrm{~cm}$. The similar water source use pattern could lead to water competition between them [21,22,81,82].

Normally, the proportion of soil water absorbed by plants increases with the rise of SWC $[48,52,83]$, which can explain our result that the proportions of the major sources of water uptake were higher in the valley than in the ridge (Figure 5). Compared to the differentiated root distribution of R. pseudoacacia (relatively shallower) and Z. jujuba (deeper) in a drier habitat, the root distribution of Z. jujuba became shallower due to improved soil and water conditions, and overlapped with R. pseudoacacia, which also exacerbated water competition in the valley. However, high-heterogeneity SWC between microtopographic sites did not change the seasonal dynamics of water source use patterns of the three species, perhaps because the difference in SWC did not reach the threshold of changing the species' water use strategy $[29,84,85]$.

\subsection{Niche Overlap in Water Source Use and Interspecies Relationship}

According to niche theory, the niche segregation of water resource use can promote species coexistence through better allocation and utilization of common resources $[28,86,87]$. The water use strategy of species is the result of environmentally induced phenotypic plasticity, adaptive evolution or both [88]. V. negundo and Z. jujuba can stably coexist in the native communities of rocky mountainous areas due to water use niche segregation. However, when $R$. pseudoacacia afforested into the native shrub community, it intensified the water use overlap with shrubs, especially Z. jujuba (Table 4). Differentiation of water use strategy exists in shrub species $V$. negundo and arbor/semi-arbor species of $R$. pseudoacacia and Z. jujuba due to the different plant growth form and root distribution feature. With the seasonal variation of water source use of $V$. negundo, the status of water use niche overlap changed. Water use sources among three species showed intensive overlap in the dry season but relieved overlap in the rainy season. In other words, $V$. negundo appeared to show niche segregation with R. pseudoacacia and Z. jujuba in the rainy season rather than in the dry season (Table 4). This result is contrary to some studies which found that co-occurring species showed ecological niche segregation of using water in the dry season to avoid drought stress, but showed niche overlap in the rainy season because of taking seasonal rainfall dominance to meet growth demand $[48,86,87]$. This result could be explained by the dimorphic rooting feature of $V$. negundo. In the dry season, $V$. negundo greatly used the tap root system to take up water in deep layer subsoil, which thereby enhanced the water competition with deep root species of R. pseudoacacia and Z. jujuba. In contrast, $V$. negundo shifted to a lower lateral root to predominantly use surface water, in contrast to the other two species, which still used deeper water in the rainy season.

After afforestation of $R$. pseudoacacia into the shrub community, the interspecific relationship between $R$. pseudoacacia and Z. jujuba is among the most important to shape the constructed community due to intensified niche overlap of water source use. In the ridge site, despite both having deeper root systems, Z. jujuba distributed a deeper root and could absorb deeper water than $R$. pseudoacacia [89-91], and thus had lesser niche overlap with the latter. However, at the valley site, the root of Z. jujuba became shallower in relatively improved water and soil conditions [82,89] and thus overlapped with $R$. 
pseudoacacia. Consequently, niche of water source use displayed more overlap in the valley than in the ridge. Moreover, shaded by clonally sprouting R. pseudoacacia in the valley, the light-demanding and drought-tolerant $Z$. jujuba grew better in the ridge than in the valley. On the contrary, R. pseudoacacia is a clonal plant with strong root sprouting [92], which leads to the competitive advantage of R. pseudoacacia over Z. jujuba in the valley. This partly explained why R. pseudoacacia grew better in the valley, whereas Z. jujuba performed well in the ridge (Table 1). Therefore, R. pseudoacacia and Z. jujuba used a similar water source and had higher niche overlap of water use sources. If $R$. pseudoacacia is used for afforestation, the site should be in the lower slope with benign soil conditions. If planted in the upper slope or ridge, R. pseudoacacia will intensify water competition and the plantation cannot persist in the long term.

\section{Conclusions}

The stable isotope-based MixSIAR model was applied to determine the spatiotemporal patterns of the water source use of planted trees R. pseudoacacia with native semi-arbor $Z$. jujuba and shrub $V$. negundo. The seasonal variation of soil water availability was similar, but it was significantly lower in the ridge than in the valley. The isotopic composition of the shallow soil water was more enriched. R. pseudoacacia and Z. jujuba can stably derive water from subsoil at a depth of $40-50 \mathrm{~cm}$ in both dry and rainy seasons, indicating higher water competition between them. However, $V$. negundo exhibited a flexible water uptake pattern which progressively switched its water source from deep to shallow soil layers as soil water availability improved from dry to rainy season. For this reason, the interspecific relationship of water source use between $V$. negundo vs. R. pseudoacacia and $V$. negundo vs. Z. jujuba was different between seasons, which indicates higher water competition in the dry season, but greater water use segregation in the rainy season. The different life form and root distribution of species contributed to various water use strategies, which importantly laid the foundation for the coexistence of the co-occurring species. Although introducing R. pseudoacacia accelerated the establishment of forest plantation and improved soil nutrient conditions, it also intensified competition for water with native species. Our study on seasonal water use source at different microsites provides an insight into the species interaction and stand selection for R. pseudoacacia afforestation in the native shrub community in rocky mountainous areas. R. pseudoacacia is better planted in the valley to avoid intense water competition and control soil erosion.

Author Contributions: Conceptualization, W.Z., P.S. and W.L.; Funding acquisition and project administration, P.S. and J.C.; W.Z. was responsible for the data collection; N.Z. helped with the statistical analysis; W.Z. and S.G. implemented the study site and investigated the vegetation stations; W.Z. wrote the original draft; P.S., J.C. and W.L. conducted the writing-review and editing. All authors have read and agreed to the published version of the manuscript.

Funding: This research was funded by the National Basic Research Program of China, grant number 2015CB452705; the National Natural Science Foundation of China, grant number 41877170; and the National Key Research and Development Program of China, grant number 2016YFC0502001.

Institutional Review Board Statement: Not applicable.

Informed Consent Statement: Not applicable.

Data Availability Statement: The data in this study are available on request from the corresponding authors.

Acknowledgments: We appreciate the reviewers and editors for thoughtful feedback that improved the manuscript. We also appreciate the help of the Hehui Wang in the Hilly Ecosystem Experimental Station of the Taihang Mountains, and the technical support of the Jintong Liu, Lipu Han, Tonggang Fu, and Hui Gao in the Key Laboratory of Agricultural Water Resources, Chinese Academy of Sciences.

Conflicts of Interest: The authors declare no conflict of interest. 


\section{References}

1. Nunez-Mir, G.C.; Iannone, B.V.; Curtis, K.; Fei, S. Evaluating the evolution of forest restoration research in a changing world: A "big literature" review. New For. 2015, 46, 669-682. [CrossRef]

2. Li, W.H. Degradation and restoration of forest ecosystems in China. For. Ecol. Manag. 2004, 201, 33-41. [CrossRef]

3. Wang, G.; Innes, J.L.; Lei, J.; Dai, S.; Wu, S.W. Ecology-China's forestry reforms. Science 2007, 318, 1556-1557. [CrossRef] [PubMed]

4. Qin, H.; Dong, G.; Zhang, Y.; Zhang, F.; Wang, M. Patterns of species and phylogenetic diversity of Pinus tabuliformis forests in the eastern Loess Plateau, China. For. Ecol. Manag. 2017, 394, 42-51. [CrossRef]

5. Yang, B.; Wen, X.; Sun, X. Seasonal variations in depth of water uptake for a subtropical coniferous plantation subjected to drought in an East Asian monsoon region. Agric. For. Meteorol. 2015, 201, 218-228. [CrossRef]

6. Cao, J.; Liu, C.; Zhang, W.; Han, S. Using temperature effect on seepage variations as proxy for phenological processes of basin-scale vegetation communities. Hydrol. Process. 2013, 27, 360-366. [CrossRef]

7. Liu, X.; Zhang, W.; Yang, F.; Zhou, X.; Liu, Z.; Qu, F.; Lian, S.; Wang, C.; Tang, X. Changes in vegetation-environment relationships over long-term natural restoration process in Middle Taihang Mountain of North China. Ecol. Eng. 2012, 49, 193-200. [CrossRef]

8. Fu, B.J.; Chen, L.D. Agricultural landscape spatial pattern analysis in the semi-arid hill area of the Loess Plateau, China. J. Arid Environ. 2000, 44, 291-303. [CrossRef]

9. McVicar, T.R.; Van Niel, T.G.; Li, L.; Wen, Z.; Yang, Q.; Li, R.; Jiao, F. Parsimoniously modelling perennial vegetation suitability and identifying priority areas to support China's re-vegetation program in the Loess Plateau: Matching model complexity to data availability. For. Ecol. Manag. 2010, 259, 1277-1290. [CrossRef]

10. Liu, X.; Lu, Y.; Xie, Y.; Xue, Y. The positive interaction between two nonindigenous species, Casuarina (Casuarina equisetifolia) and Acacia (Acacia mangium), in the tropical coastal zone of south China: Stand dynamics and soil nutrients. Trop. Conserv. Sci. 2015, 8 , 598-609. [CrossRef]

11. Cao, S.; Tian, T.; Chen, L.; Dong, X.; Yu, X.; Wang, G. Damage caused to the environment by reforestation policies in arid and semi-arid areas of China. Ambio 2010, 39, 279-283. [CrossRef] [PubMed]

12. Cao, S.; Chen, L.; Shankman, D.; Wang, C.; Wang, X.; Zhang, H. Excessive reliance on afforestation in China's arid and semi-arid regions: Lessons in ecological restoration. Earth-Sci. Rev. 2011, 104, 240-245. [CrossRef]

13. Liu, J.; Yang, Z.; Dang, P.; Zhu, H.; Gao, Y.; Ha, V.N.; Zhao, Z. Response of soil microbial community dynamics to Robinia pseudoacacia L. afforestation in the Loess Plateau: A chronosequence approach. Plant Soil 2017, 423, 327-338. [CrossRef]

14. Yang, X.; Yan, D.; Liu, C. Natural regeneration of trees in three types of afforested stands in the Taihang Mountains, China. PLoS ONE 2014, 9. [CrossRef]

15. Kou, M.; Garcia-Fayos, P.; Hu, S.; Jiao, J. The effect of Robinia pseudoacacia afforestation on soil and vegetation properties in the Loess Plateau (China): A chronosequence approach. For. Ecol. Manag. 2016, 375, 146-158. [CrossRef]

16. Xu, Y.; Zhang, W.; Zhong, Z.; Guo, S.; Han, X.; Yang, G.; Ren, C.; Chen, Z.; Dai, Y.; Qiao, W. Vegetation restoration alters the diversity and community composition of soil nitrogen-fixing microorganisms in the Loess Hilly Region of China. Soil Sci. Soc. Am. J. 2019, 83, 1378-1386. [CrossRef]

17. Zhang, Q.; Wei, W.; Chen, L.; Yang, L. The joint effects of precipitation gradient and afforestation on soil moisture across the Loess Plateau of China. Forests 2019, 10, 285. [CrossRef]

18. Bowling, D.R.; Schulze, E.S.; Hall, S.J. Revisiting streamside trees that do not use stream water: Can the two water worlds hypothesis and snowpack isotopic effects explain a missing water source? Ecohydrology 2016, 10, e1771. [CrossRef]

19. Eggemeyer, K.D.; Awada, T.; Harvey, F.E.; Wedin, D.A.; Zhou, X.; Zanner, C.W. Seasonal changes in depth of water uptake for encroaching trees Juniperus virginiana and Pinus ponderosa and two dominant C4 grasses in a semiarid grassland. Tree Physiol. 2009, 29, 157-169. [CrossRef]

20. Grossiord, C.; Sevanto, S.; Dawson, T.E.; Adams, H.D.; Collins, A.D.; Dickman, L.T.; Newman, B.D.; Stockton, E.A.; McDowell, N.G. Warming combined with more extreme precipitation regimes modifies the water sources used by trees. New Phytol. 2017, 213, 584-596. [CrossRef]

21. Liu, Z.; Yu, X.; Jia, G.; Jia, J.; Lou, Y.; Lu, W. Contrasting water sources of evergreen and deciduous tree species in rocky mountain area of Beijing, China. Catena 2017, 150, 108-115. [CrossRef]

22. Nippert, J.B.; Knapp, A.K. Soil water partitioning contributes to species coexistence in tallgrass prairie. Oikos 2007, 116, 1017-1029. [CrossRef]

23. Sun, S.J.; Meng, P.; Zhang, J.S.; Wan, X. Variation in soil water uptake and its effect on plant water status in Juglans regia L. during dry and wet seasons. Tree Physiol. 2011, 31, 1378-1389. [CrossRef] [PubMed]

24. Tao, F.; Zhang, Z. Adaptation of maize production to climate change in North China Plain: Quantify the relative contributions of adaptation options. Eur. J. Agron. 2010, 33, 103-116. [CrossRef]

25. Gao, X.; Wu, P.; Zhao, X.; Shi, Y.; Wang, J.; Zhang, B. Soil moisture variability along transects over a well-developed gully in the Loess Plateau, China. Catena 2011, 87, 357-367. [CrossRef]

26. Moreno-de las Heras, M.; Espigares, T.; Merino-Martín, L.; Nicolau, J.M. Water-related ecological impacts of rill erosion processes in Mediterranean-dry reclaimed slopes. Catena 2011, 84, 114-124. [CrossRef] 
27. Guderle, M.; Bachmann, D.; Milcu, A.; Gockele, A.; Bechmann, M.; Fischer, C.; Roscher, C.; Landais, D.; Ravel, O.; Devidal, S.; et al. Dynamic niche partitioning in root water uptake facilitates efficient water use in more diverse grassland plant communities. Funct. Ecol. 2017, 32, 214-227. [CrossRef]

28. Levine, J.M.; HilleRisLambers, J. The importance of niches for the maintenance of species diversity. Nature 2009, 461, 254-257. [CrossRef] [PubMed]

29. Ward, D.; Wiegand, K.; Getzin, S. Walter's two-layer hypothesis revisited: Back to the roots! Oecologia 2013, 172, 617-630. [CrossRef] [PubMed]

30. Dai, Y.; Zheng, X.J.; Tang, L.S.; Li, Y. Stable oxygen isotopes reveal distinct water use patterns of two Haloxylon species in the Gurbantonggut Desert. Plant Soil 2015, 389, 73-87. [CrossRef]

31. Rossatto, D.R.; da Silveira Lobo Sternberg, L.; Franco, A.C. The partitioning of water uptake between growth forms in a neotropical savanna: Do herbs exploit a third water source niche? Plant Biol. 2013, 15, 84-92. [CrossRef] [PubMed]

32. Wu, Y.; Zhou, H.; Zheng, X.J.; Li, Y.; Tang, L.S. Seasonal changes in the water use strategies of three co-occurring desert shrubs. Hydrol. Process. 2014, 28, 6265-6275. [CrossRef]

33. Yang, H.; Auerswald, K.; Bai, Y.; Han, X. Complementarity in water sources among dominant species in typical steppe ecosystems of Inner Mongolia, China. Plant Soil 2011, 340, 303-313. [CrossRef]

34. Zunzunegui, M.; Boutaleb, S.; Diaz Barradas, M.C.; Esquivias, M.P.; Valera, J.; Jauregui, J.; Tagma, T.; Ain-Lhout, F. Reliance on deep soil water in the tree species Argania spinosa. Tree Physiol. 2018, 38, 678-689. [CrossRef]

35. David, T.S.; Henriques, M.O.; Kurz-Besson, C.; Nunes, J.; Valente, F.; Vaz, M.; Pereira, J.S.; Siegwolf, R.; Chaves, M.M.; Gazarini, L.C.; et al. Water-use strategies in two co-occurring Mediterranean evergreen oaks: Surviving the summer drought. Tree Physiol. 2007, 27, 793-803. [CrossRef] [PubMed]

36. Ehleringer, J.R.; Dawson, T.E. Water uptake by plants: Perspectives from stable isotope composition. Plant Cell Environ. 1992, 15, 1073-1082. [CrossRef]

37. Ohte, N.; Koba, K.; Yoshikawa, K.; Sugimoto, A.; Matsuo, N.; Kabeya, N.; Wang, L. Water utilization of natural and planted trees in the semiarid desert of Inner Mongolia, China. Ecol. Appl. 2003, 13, 337-351. [CrossRef]

38. Valentini, R.; Mugnozza, G.E.S.; Ehleringer, J.R. Hydrogen and carbon isotope ratios of selected species of a Mediterranean Macchia Ecosystem. Funct. Ecol. 1992, 6, 627. [CrossRef]

39. Williams, D.G.; Ehleringer, J.R. Intra- and interspecific variation for summer precipitation use in Pinyon-Juniper Woodlands. Ecol. Monogr. 2000, 70, 517-537. [CrossRef]

40. Wu, H.; Li, X.Y.; Jiang, Z.; Chen, H.; Zhang, C.; Xiao, X. Contrasting water use pattern of introduced and native plants in an alpine desert ecosystem, Northeast Qinghai-Tibet Plateau, China. Sci. Total Environ. 2016, 542, 182-191. [CrossRef]

41. Walter, H. Ecology of Tropical and Subtropical Vegetation; Oliver \& Boyd: Edinburgh, UK, 1971; Volume 28, p. 165. [CrossRef]

42. Penna, D.; Oliviero, O.; Assendelft, R.; Zuecco, G.; van Meerveld, I.; Anfodillo, T.; Carraro, V.; Borga, M.; Dalla Fontana, G. Tracing the water sources of trees and streams: Isotopic analysis in a small pre-alpine catchment. In Proceedings of the Four Decades of Progress in Monitoring and Modeling of Processes in the Soil-Plant-Atmosphere System: Applications and Challenges, Italy, 19-21 June 2013; Romano, N., Durso, G., Severino, G., Chirico, G.B., Palladino, M., Eds.; Elsevier Procedia Environmental Sciences: Amsterdam, The Netherlands, 2013; Volume 19, pp. 106-112.

43. White, J.C.; Smith, W.K. Seasonal variation in water sources of the riparian tree species Acer negundo and Betula nigra, southern Appalachian foothills, USA. Botany 2015, 93, 519-528. [CrossRef]

44. Barbeta, A.; Mejia-Chang, M.; Ogaya, R.; Voltas, J.; Dawson, T.E.; Penuelas, J. The combined effects of a long-term experimental drought and an extreme drought on the use of plant-water sources in a Mediterranean forest. Glob. Chang. Biol. 2015, 21, 1213-1225. [CrossRef] [PubMed]

45. Wei, Y.F.; Fang, J.; Liu, S.; Zhao, X.Y.; Li, S.G. Stable isotopic observation of water use sources of Pinus sylvestris var. mongolica in Horqin Sandy Land, China. Trees-Struct. Funct. 2013, 27, 1249-1260. [CrossRef]

46. De Deurwaerder, H.; Herve-Fernandez, P.; Stahl, C.; Burban, B.; Petronelli, P.; Hoffman, B.; Bonal, D.; Boeckx, P.; Verbeeck, H. Liana and tree below-ground water competition-evidence for water resource partitioning during the dry season. Tree Physiol. 2018, 38, 1071-1083. [CrossRef]

47. Antunes, C.; Díaz-Barradas, M.C.; Zunzunegui, M.; Vieira, S.; Máguas, C.; Paruelo, J. Water source partitioning among plant functional types in a semi-arid dune ecosystem. J. Veg. Sci. 2018, 29, 671-683. [CrossRef]

48. Guo, J.S.; Hungate, B.A.; Kolb, T.E.; Koch, G.W. Water source niche overlap increases with site moisture availability in woody perennials. Plant Ecol. 2018, 219, 719-735. [CrossRef]

49. Higgins, S.I.; Delgado-Cartay, M.D.; February, E.C.; Combrink, H.J. Is there a temporal niche separation in the leaf phenology of savanna trees and grasses? J. Biogeogr. 2011, 38, 2165-2175. [CrossRef]

50. Saha, A.K.; da Silveira Lobo O'Reilly Sternberg, L.; Miralles-Wilhelm, F. Linking water sources with foliar nutrient status in upland plant communities in the Everglades National Park, USA. Ecohydrology 2009, 2, 42-54. [CrossRef]

51. Antunes, C.; Díaz Barradas, M.C.; Zunzunegui, M.; Vieira, S.; Pereira, Â.; Anjos, A.; Correia, O.; Pereira, M.J.; Máguas, C.; Llorens, L. Contrasting plant water-use responses to groundwater depth in coastal dune ecosystems. Funct. Ecol. 2018, 32, 1931-1943. [CrossRef]

52. Drake, P.L.; Franks, P.J. Water resource partitioning, stem xylem hydraulic properties, and plant water use strategies in a seasonally dry riparian tropical rainforest. Oecologia 2003, 137, 321-329. [CrossRef] 
53. Máguas, C.; Rascher, K.G.; Martins-Loução, A.; Carvalho, P.; Pinho, P.; Ramos, M.; Correia, O.; Werner, C. Responses of woody species to spatial and temporal ground water changes in coastal sand dune systems. Biogeosciences 2011, 8, 3823-3832. [CrossRef]

54. Si, J.; Feng, Q.; Cao, S.; Yu, T.; Zhao, C. Water use sources of desert riparian Populus euphratica forests. Environ. Monit. Assess. 2014, 186, 5469-5477. [CrossRef] [PubMed]

55. Zhang, Y.W.; Deng, L.; Yan, W.M.; Shangguan, Z.P. Interaction of soil water storage dynamics and long-term natural vegetation succession on the Loess Plateau, China. Catena 2016, 137, 52-60. [CrossRef]

56. Han, S.; Yang, Y.; Fan, T.; Xiao, D.; Moiwo, J.P. Precipitation-runoff processes in Shimen hillslope micro-catchment of Taihang Mountain, north China. Hydrol. Process. 2012, 26, 1332-1341. [CrossRef]

57. Liang, H.; Xue, Y.; Li, Z.; Wang, S.; Wu, X.; Gao, G.; Liu, G.; Fu, B. Soil moisture decline following the plantation of Robinia pseudoacacia forests: Evidence from the Loess Plateau. For. Ecol. Manag. 2018, 412, 62-69. [CrossRef]

58. Liu, X.P.; Zhang, W.J.; Hu, C.S.; Tang, X.G. Soil greenhouse gas fluxes from different tree species on Taihang Mountain, North China. Biogeosciences 2014, 11, 1649-1666. [CrossRef]

59. Zeng, X.; Zhang, W.; Shen, H.; Cao, J.; Zhao, X. Soil respiration response in different vegetation types at Mount Taihang, China. Catena 2014, 116, 78-85. [CrossRef]

60. Martí-Gómez, P.; Serrano, L.; Ferrio, J.P. Short-term dynamics of evaporative enrichment of xylem water in woody stems: Implications for ecohydrology. Tree Physiol. 2017, 37, 511-522. [CrossRef]

61. Wang, S.; Zheng, W.; Currell, M.; Yang, Y.; Zhao, H.; Lv, M. Relationship between land-use and sources and fate of nitrate in groundwater in a typical recharge area of the North China Plain. Sci. Total Environ. 2017, 609, 607-620. [CrossRef]

62. Parnell, A.C.; Inger, R.; Bearhop, S.; Jackson, A.L. Source partitioning using stable isotopes: Coping with too much variation. PLOS ONE 2010, 5, e9672. [CrossRef]

63. Stock, B.C.; Semmens, B.X. Unifying error structures in commonly used biotracer mixing models. Ecology 2016, 97, 2562-2569. [CrossRef] [PubMed]

64. Wang, J.; Lu, N.; Fu, B. Inter-comparison of stable isotope mixing models for determining plant water source partitioning. Sci. Total Environ. 2019, 666, 685-693. [CrossRef] [PubMed]

65. Dawson, T.E.; Pate, J.S. Seasonal water uptake and movement in root systems of Australian phraeatophytic plants of dimorphic root morphology: A stable isotope investigation. Oecologia 1996, 107, 13-20. [CrossRef] [PubMed]

66. Wang, J.; Fu, B.; Lu, N.; Zhang, L. Seasonal variation in water uptake patterns of three plant species based on stable isotopes in the semi-arid Loess Plateau. Sci. Total Environ. 2017, 609, 27-37. [CrossRef]

67. Stock, B.C.; Semmens, B.X. MixSIAR User Manual, version 3.1; A framework for Bayesian mixing models in R; GitHub: San Francisco, CA, USA, 2013.

68. Trogisch, S.; Salmon, Y.; He, J.S.; Hector, A.; Scherer-Lorenzen, M. Spatio-temporal water uptake patterns of tree saplings are not altered by interspecific interaction in the early stage of a subtropical forest. For. Ecol. Manag. 2016, 367, 52-61. [CrossRef]

69. Hoekstra, N.J.; Finn, J.A.; Hofer, D.; Lüscher, A. The effect of drought and interspecific interactions on depth of water uptake in deep- and shallow-rooting grassland species as determined by $\delta^{18} \mathrm{O}$ natural abundance. Biogeosciences 2014, 11, 4493-4506. [CrossRef]

70. Gazis, C.; Feng, X. A stable isotope study of soil water: Evidence for mixing and preferential flow paths. Geoderma 2004, 119, 97-111. [CrossRef]

71. Tang, K.; Feng, X. The effect of soil hydrology on the oxygen and hydrogen isotopic compositions of plants' source water. Earth Planet. Sci. Lett. 2001, 185, 355-367. [CrossRef]

72. Deng, W.; Yu, X.X.; Jia, G.; Li, Y.; Liu, Y. An analysis of characteristics of hydrogen and oxygen stable isotopes in Jiufeng Mountain areas of Beijing. Adv. Water Sci. 2013, 24, 642-650. [CrossRef]

73. Zhao, W.; Chen, S.P.; Han, X.G.; Lin, G.H. Effects of long-term grazing on the morphological and functional traits of Leymus chinensis in the semiarid grassland of Inner Mongolia, China. Ecol. Res. 2009, 24, 99-108. [CrossRef]

74. Liu, Y.; Zhang, X.; Zhao, S.; Ma, H.; Qi, G.; Guo, S. The depth of water taken up by walnut trees during different phenological stages in an irrigated arid hilly area in the Taihang Mountains. Forests 2019, 10, 121. [CrossRef]

75. Zhao, H.; Wang, Q.R.; Fan, W.; Song, G.H. The relationship between secondary forest and environmental factors in the Southern Taihang Mountains. Sci. Rep. 2017, 7. [CrossRef] [PubMed]

76. Nie, Y.P.; Chen, H.S.; Wang, K.L.; Tan, W.; Deng, P.Y.; Yang, J. Seasonal water use patterns of woody species growing on the continuous dolostone outcrops and nearby thin soils in subtropical China. Plant Soil 2011, 341, 399-412. [CrossRef]

77. Burgess, S.S.; Adams, M.A.; Turner, N.C.; Ong, C.K. The redistribution of soil water by tree root systems. Oecologia 1998, 115, 306-311. [CrossRef] [PubMed]

78. Hultine, K.R.; Williams, D.G.; Burgess, S.S.; Keefer, T.O. Contrasting patterns of hydraulic redistribution in three desert phreatophytes. Oecologia 2003, 135, 167-175. [CrossRef] [PubMed]

79. Midwood, A.J.; Boutton, T.W.; Archer, S.R.; Watts, S.E. Water use by woody plants on contrasting soils in a savanna parkland: Assessment with delta H-2 and delta O-18. Plant Soil 1998, 205, 13-24. [CrossRef]

80. Zou, C.B.; Barnes, P.W.; Archer, S.; McMurtry, C.R. Soil moisture redistribution as a mechanism of facilitation in savanna tree-shrub clusters. Oecologia 2005, 145, 32-40. [CrossRef] [PubMed]

81. Monaco, T.A.; Johnson, D.A.; Creech, J.E. Morphological and physiological responses of the invasive weed Isatis tinctoria to contrasting light, soil-nitrogen and water. Weed Res. 2005, 45, 460-466. [CrossRef] 
82. Zhu, J.; Liu, J.; Lu, Z.; Li, J.; Sun, J. Water-use strategies of coexisting shrub species in the Yellow River Delta, China. Can. J. For. Res. 2018, 48, 1099-1107. [CrossRef]

83. Zhang, C.; Zhang, J.; Zhao, B.; Zhu, A.; Zhang, H.; Huang, P.; Li, X. Coupling a two-tip linear mixing model with a $\delta \mathrm{D}-\delta^{18} \mathrm{O}$ plot to determine water sources consumed by maize during different growth stages. Field Crop. Res. 2011, 123, 196-205. [CrossRef]

84. Dawson, T.E.; Mambelli, S.; Plamboeck, A.H.; Templer, P.H.; Tu, K.P. Stable isotopes in plant ecology. Annu. Rev. Ecol. Syst. 2002, 33, 507-559. [CrossRef]

85. Ma, H.; Zhu, Q.; Zhao, W. Soil water response to precipitation in different micro-topographies on the semi-arid Loess Plateau, China. J. For. Res. 2018, 31, 245-256. [CrossRef]

86. Araya, Y.N.; Silvertown, J.; Gowing, D.J.; McConway, K.J.; Linder, H.P.; Midgley, G. A fundamental, eco-hydrological basis for niche segregation in plant communities. New Phytol. 2011, 189, 253-258. [CrossRef]

87. Silvertown, J. Plant coexistence and the niche. Trends Ecol. Evol. 2004, 19, 605-611. [CrossRef]

88. Mazer, S.J.; Dudley, L.S.; Hove, A.A.; Emms, S.K.; Verhoeven, A.S. Physiological performance in Clarkia sister taxa with contrasting mating systems: Do early-flowering autogamous taxa avoid water stress relative to their pollinator-dependent counterparts? Int J. Plant Sci. 2010, 171, 1029-1047. [CrossRef]

89. Zhang, C.; Chen, L.; Jiang, J. Vertical root distribution and root cohesion of typical tree species on the Loess Plateau, China. J. Arid Land 2014, 6, 601-611. [CrossRef]

90. Li, L.; Gao, X.; Wu, P.; Zhao, X.; Li, H.; Ling, Q.; Sun, W. Soil water content and root patterns in a rain-fed jujube plantation across stand ages on the Loess Plateau of China. Land Degrad. Dev. 2017, 28, 207-216. [CrossRef]

91. Mei, X.; Zhu, Q.; Ma, L.; Zhang, D.; Wang, Y.; Hao, W. Effect of stand origin and slope position on infiltration pattern and preferential flow on a Loess hillslope. Land Degrad. Dev. 2018, 29, 1353-1365. [CrossRef]

92. Nicolescu, V.-N.; Redei, K.; Mason, W.L.; Vor, T.; Poeetzelsberger, E.; Bastien, J.-C.; Brus, R.; Bencat, T.; Dodan, M.; Cvjetkovic, B.; et al. Ecology, growth and management of black locust (Robinia pseudoacacia L.), a non-native species integrated into European forests. J. For. Res. 2020, 31, 1081-1101. [CrossRef] 